Article

\title{
Dynamics Affect Nitrogen Retention, Ileal Amino Acid Digestibility, and Gene Expression Levels of Digestive Enzymes at Three Stages in Pigs Fed Two Levels of Low-Protein Diets
}

\author{
Li Wu ${ }^{1,2,+}$, Qinghua $\mathrm{He}^{2,+}$, Wen Zhen ${ }^{2,+}$, Tiejun $\mathrm{Li}^{2}$, Peng Liao ${ }^{2, *}$. \\ 1 Department of food science and engineering, College of chemistry and environmental engineering, \\ Shenzhen University, Shenzhen, 518060 China; adonis5@163.com (L.W.); heqinghua2005@gmail.com (Q.H.); \\ wenzhen@szu.edu.cn(W.Z.); \\ 2 Institute of Subtropical Agriculture, Chinese Academy of Sciences, Changsha 410125, Hunan, China; \\ tjli@isa.ac.cn (T.J.) \\ 3 Department of gynaecology and obstetrics, Mawangdui District of Hunan Provincial People's Hospital, \\ Guhan Road, Changsha 410016, Hunan Province, China; \\ + These authors contributed equally to this work. \\ * Correspondence: liaopeng@isa.ac.cn (P.L.); \\ Tel.:+86-731-8461-9703; Fax: +86-731-8461-2685
}

\begin{abstract}
This study was conducted to determine the dynamic effects of dietary crude protein $(\mathrm{CP})$ intake on nitrogen $(\mathrm{N})$ balance, ileal amino acid digestibility, and gene expression levels of digestive enzymes at three stages in pigs. In Experiment 1, 18 growing pigs (average body weight $(\mathrm{BW})=9.5 \mathrm{~kg}$ ) were randomly assigned to one of three treatments $(\mathrm{n}=6 /$ treatment group$)$, including normal $(20 \% \mathrm{CP})$, low $(17 \% \mathrm{CP})$, and very low $(14 \% \mathrm{CP})$ protein intake. In Experiment 2 , 18 growing pigs (average $\mathrm{BW}=30 \mathrm{~kg}$ ) were allotted randomly to one of three treatments $(\mathrm{n}=$ $6 /$ treatment group), including normal $(18 \% \mathrm{CP})$, low $(15 \% \mathrm{CP})$, and very low $(12 \% \mathrm{CP})$ protein intake. In Experiment 3, 18 growing pigs (average $\mathrm{BW}=45 \mathrm{~kg}$ ) were assigned randomly to one of three treatments $(n=6 /$ treatment group), including normal $(16 \% \mathrm{CP})$, low $(13 \% \mathrm{CP})$, and very low $(10 \% \mathrm{CP})$ protein intake. Growing pigs fed the $14 \% \mathrm{CP}$ and $17 \% \mathrm{CP}$ diets had lower final BW (P < $0.05)$ and average daily gain $(\mathrm{ADG})(\mathrm{P}<0.05)$ compared to pigs fed the $20 \% \mathrm{CP}$ diet. Reducing the dietary CP level from 20 to $14 \%$ decreased urinary $\mathrm{N}$ excretion by $52.8 \%(\mathrm{P}<0.001)$ in Experiment 1. Reducing the dietary $\mathrm{CP}$ level from 18 to $12 \%$ decreased urinary $\mathrm{N}$ excretion by $55.3 \%(\mathrm{P}<0.001)$ and reduced fecal $\mathrm{N}$ excretion by $34 \%(\mathrm{P}<0.05)$ in Experiment 2 . Reducing the dietary $\mathrm{CP}$ level from 16 to $10 \%$ decreased urinary $\mathrm{N}$ excretion by $56.4 \%(\mathrm{P}<0.001)$ and fecal $\mathrm{N}$ excretion by $47.1 \%$ $(\mathrm{P}<0.001)$ in Experiment 3. Pigs fed the very low $(14 \%, 12 \%$, and $10 \% \mathrm{CP})$ diets showed higher digestibility for $\mathrm{CP}(\mathrm{P}<0.05)$, His $(\mathrm{P}<0.05)$, Ile $(\mathrm{P}<0.05)$, Phe $(\mathrm{P}<0.05)$, Thr $(\mathrm{P}<0.05)$, $\operatorname{Tr} \mathrm{P}(\mathrm{P}<0.05)$, Glu $(\mathrm{P}<0.05)$, and Ser $(\mathrm{P}<0.05)$ compared to pigs fed the normal $(20 \%, 18 \%$, and $16 \% \mathrm{CP})$ diets among the three experiments. Pigs fed the very low $(14 \%, 12 \%$, and $10 \% \mathrm{CP})$ diets showed higher mRNA levels for chymotrypsin $\mathrm{C}(\mathrm{P}<0.01$ in Experiment 1 and 2; $\mathrm{P}<0.05$ in Experiment 3) compared to pigs fed the normal $(20 \%, 18 \%$, and $16 \% \mathrm{CP})$ diets among the three experiments. These results indicated that a reduction in dietary $\mathrm{CP}$ by $6 \%$ limited the growth performance of growing pigs, and a reduction of dietary $\mathrm{CP}$ by $3 \%$ supplemented with essential amino acids could reduce the excretion of $\mathrm{N}$ into the environment without affecting weight gain.
\end{abstract}

Keywords: amino acid; digestive enzyme; low protein diet; nitrogen balance; pigs

\section{Introduction}


Amino acid (AA) nutrition plays important roles in global animal production progress, such as facilitating increased growth and health status and stimulated immunity function[1]. Studies have shown that a diet containing low crude protein (CP) supplemented with AA may reduce diarrhea in weaning pigs, boost feed economy, repair digestive function (including gene expression alterations of digestive enzymes) by increasing the digestion and absorption of AA, and reduce nitrogen $(\mathrm{N})$, which excretion contributes appreciably to environmental pollution[2-7]. However, there are discrepancies among these studies concerning the extent to which the $\mathrm{CP}$ level of diets from growing pigs to finishing pigs can be reduced. First, a CP reduction of 2- to $3 \%$ is can be made without affecting average daily gain (ADG) or feed efficiency when diets are supplemented with AA [8,9]. Second, some reports have shown that reductions exceeding 3\% also have no effects on ADG, feed efficiency and mRNA levels of digestive enzymes (including trypsinogen, chymotrypsin $B$, and dipeptidase-II and III) [2,10,11], but that trend has not always been observed in other reports [12-14]. A possible explanation for these discrepancies is that in some studies, the standard diet may have exceeded the AA requirements for single- or multiple stages in pigs. However, in other studies, the standard diets may have only just met or been slightly below the AA requirements for single- or multiple stages in pigs. Therefore, there are limited reports related to the dynamics and continuous research for different stages of pigs.

To enhance the current understanding of the dynamics and continuous effects of reductions in $\mathrm{CP}$, we devised an experiment to evaluate the dynamic effects on growth performance, $\mathrm{N}$ balance, ileal amino acid digestibility, and gene expression levels of digestive enzymes after feeding two levels of low $\mathrm{CP}$ diets in three stages of pigs.

\section{Materials and Methods}

\subsection{Ethics statement}

This study was conducted according to the guidelines of the Declaration of Institute, and all procedures involving animal subjects were approved by the animal welfare committee of the Institute of Subtropical Agriculture at the Chinese Academy of Sciences (Changsha, Hunan Province, China, No.: 20150607).

\subsection{Experimental design and procedure}

All of the cross-bred pigs [Yorkshire $\times($ Duroc $\times$ Landrace)] (Hunan New Wellful Co., Ltd., Hunan Province, China) were assigned randomly to one of three diet treatments (6 pigs/group), including very low (Group A), low (Group B) and normal (Group C) dietary intake of CP. All of the pigs were housed individually in metabolism cages, and had free access to feedstuff and drinking water. The temperature in the metabolism room was maintained at approximately $24^{\circ} \mathrm{C}$ and light was provided continuously. Titanium dioxide (TiQ2) $(1 \mathrm{~g} / \mathrm{kg}$ diet) was added to all experiment diets and served as an indigestion marker to calculate total tract $\mathrm{N}$ digestibility [15]. There were 3-separate experiments involving 18 growing pigs (Experiment 1), 18 growing pigs (Experiment 2), and 18 finishing pigs (Experiment 3). The experimental design and procedure are shown in Figure 1. All of the experiment diets were formulated according to the National Research Council (NRC, 2012) to meet the nutrient requirements for growing pigs and finishing pigs [16]. There was a 3-day acclimatization period prior the commencing of each experiment. The results of body weight (BW) and feed consumption, such as average daily gain (ADG), average daily feed intake (ADFI), and the ratio of feed and gain $(\mathrm{F}: \mathrm{G})$, were recorded at the beginning and end of the experiment period.

\subsection{Experiment 1}

A total of eighteen [Yorkshire $\times$ (Duroc $\times$ Landrace)] (Hunan New Wellful Co., Ltd., Hunan Province, China) cross-bred growing pigs with an average BW of $9.51 \pm 0.75 \mathrm{~kg}$ were assigned randomly to one of three dietary CP levels: very low (14\% CP, Group A), low (17\% CP, Group B), and normal $(20 \%$ CP, Group C) CP. The dietary treatments devised as Group A and B were supplemented with some AA that are not synthesized in a pig's body (L-lysine, L-methionine, 
L-threonine, and L-tryptophan) to meet the National Research Council (NRC, 2012) nutrient requirements for growing pigs[16]. The experiments lasted 45 days. The experimental diet ingredients and nutrient compositions in this experiment are shown in Table 1.

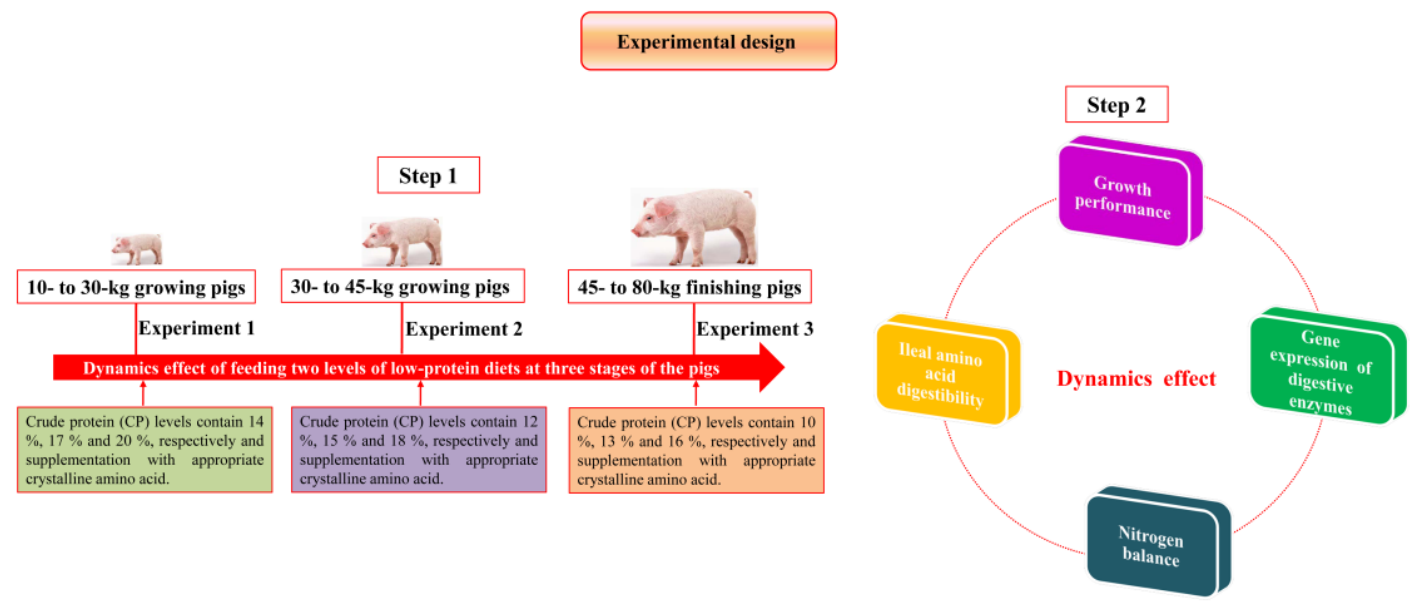

Figure 1 Experimental design. There were 3-separate experiments involving 18 [Yorkshire $\times$ (Duroc $\times$ Landrace)] growing pigs (Experiment 1), 18 [Yorkshire $\times$ (Duroc $\times$ Landrace)] growing pigs (Experiment 2), and 18 [Yorkshire $\times($ Duroc $\times$ Landrace)] finishing pigs (Experiment 3$)$. Experiment 1 : Group A = 14\% CP (very low CP level); Group B =17\% CP (low CP level); Group C $=20 \%$ CP (normal $\mathrm{CP}$ level). Groups A and B had diets supplemented with L-lysine, L-methionine, L-threonine, and L-tryptophan (see Table 1). Experiment 2: Group A = 12\% CP (very low CP level); Group B = 15\% CP (low CP level); Group C = 18\% CP (normal CP level). Groups A and B had diets supplemented with L-lysine, L-methionine, L-threonine, and L-tryptophan (see Table 2). Experiment 3: Group A = 10\% $\mathrm{CP}$ (very low CP level); Group B = 13\% CP (low CP level); Group C = 16\% CP (normal CP level). Groups $\mathrm{A}$ and $\mathrm{B}$ had diets supplemented with L-lysine, L-methionine, L-threonine, and L-tryptophan. $\mathrm{CP}=$ crude protein.

\subsection{Experiment 2}

A total of eighteen [Yorkshire $\times($ Duroc $\times$ Landrace)] (Hunan New Wellful Co., Ltd., Hunan Province, China) cross-bred growing pigs with an average BW of $29.12 \pm 2.30 \mathrm{~kg}$ were assigned randomly to one of three dietary CP levels: very low (12\% CP, Group A), low (15\% CP, Group B), and normal (18\% CP, Group C) CP. The dietary treatments devised as Group A and B were supplemented with some AA that are not synthesized in a pig's (L-lysine, L-methionine, L-threonine, and L-tryptophan) to meet the National Research Council (NRC, 2012) nutrient requirements for growing pigs[16]. The experiments lasted 30 days. The experimental diets of ingredients and nutrient compositions in this experiment are shown in Table 2.

\subsection{Experiment 3}

A total of eighteen [Yorkshire $\times($ Duroc $\times$ Landrace)] (Hunan New Wellful Co., Ltd., Hunan Province, China) cross-bred finishing pigs with an average BW of $45.00 \pm 2.07 \mathrm{~kg}$ were assigned randomly to one of three dietary $\mathrm{CP}$ levels: very low $(10 \% \mathrm{CP}$, group $\mathrm{A})$, low $(13 \% \mathrm{CP}$, group $\mathrm{B})$, and normal (16\% CP, group C) CP. The dietary treatments for Groups A and B were supplemented with some AA that are not synthesized in the pig body (L-lysine, L-methionine, L-threonine and L-tryptophan) to meet the National Research Council (NRC, 2012) nutrient requirements for finishing pigs[16]. The experiments lasted 50 days. The experimental diets of ingredients and nutrient compositions in this experiment are shown in Table 3.

\subsection{Sample collection and preparation}


At the end of each experiment, pigs were anesthetized through an intravenous injection of 50 $\mathrm{mg} / \mathrm{kg}$ sodium pentobarbital and then sacrificed. The collection period was divided into parts to conduct experiments on apparent digestibility and $\mathrm{N}$ balance (days 3-7), and all the samples of intestine (duodenum and jejunum) were removed, collected and immediately frozen in liquid nitrogen at $-80 \mathrm{oC}$ for subsequent analysis of gene expression levels as previously described [2,17]. The digesta samples were collected from the ileum for analyzing the digestibility of energy (DE), dry matter (DM), CP, and AA as previously described [2].

Table 1. Feedstuff ingredients and nutrient composition of experimental diets for $10-$ to $30-\mathrm{kg}$ growing pigs (\%).

\begin{tabular}{|c|c|c|c|}
\hline \multirow{2}{*}{ Feed ingredient } & \multicolumn{3}{|c|}{ CP levelsa } \\
\hline & $14 \% \mathrm{CP}$ & $17 \% \mathrm{CP}$ & $20 \%$ CP \\
\hline Corn $(43 \% \mathrm{CP})$ & 71.80 & 66.50 & 63.70 \\
\hline Soybean meal & 13.40 & 18.80 & 19.80 \\
\hline Whey powder & 4.40 & 4.30 & 4.30 \\
\hline Fish meal $(64 \% \mathrm{CP})$ & 1.50 & 4.00 & 9.00 \\
\hline Soybean oil & 4.10 & 2.60 & 0.80 \\
\hline Lysine hydrochloride & 0.88 & 0.62 & 0.38 \\
\hline Hydroxy methionine & 0.27 & 0.19 & 0.10 \\
\hline L-threonine & 0.33 & 0.21 & 0.09 \\
\hline L-tryptophan & 0.08 & 0.04 & 0.01 \\
\hline CaHPO3 & 1.15 & 0.74 & 0.00 \\
\hline Rock-powder & 0.79 & 0.70 & 0.52 \\
\hline Salt & 0.30 & 0.30 & 0.30 \\
\hline $1 \%$ Premix $^{b}$ & 1.00 & 1.00 & 1.00 \\
\hline Total & 100.00 & 100.00 & 100.00 \\
\hline \multicolumn{4}{|c|}{ Calculated and analyzed nutrient composition ${ }^{c}$} \\
\hline $\mathrm{DE}(\mathrm{MJ} / \mathrm{kg})$ & 14.60 & 14.60 & 14.60 \\
\hline $\mathrm{CP}$ & 14.14 & 17.32 & 20.27 \\
\hline Total Ca & 0.70 & 0.71 & 0.69 \\
\hline Total P & 0.53 & 0.55 & 0.57 \\
\hline Starch & 45.16 & 41.95 & 40.22 \\
\hline NDF & 8.40 & 8.66 & 8.54 \\
\hline $\mathrm{ADF}$ & 3.05 & 3.30 & 3.29 \\
\hline Lys & 1.26 & 1.25 & 1.26 \\
\hline Met + Cys & 0.63 & 0.65 & 0.62 \\
\hline Thr & 0.76 & 0.75 & 0.76 \\
\hline $\operatorname{Trp}$ & 0.20 & 0.20 & 0.20 \\
\hline Arg & 0.71 & 0.93 & 1.09 \\
\hline His & 0.30 & 0.37 & 0.44 \\
\hline Ile & 0.46 & 0.60 & 0.71 \\
\hline Leu & 1.11 & 1.32 & 1.52 \\
\hline Phe & 0.56 & 0.70 & 0.81 \\
\hline Val & 0.54 & 0.64 & 0.72 \\
\hline
\end{tabular}

aDiet treatment: Crude protein (CP) levels contain $14 \%, 17 \%$ and $20 \%$, respectively and supplementation with appropriate crystalline AA. bPremix provided these amounts of vitamins and minerals per kilogram on an as-fed basis: vitamin A, 10,800 IU; vitamin D3, 4,000 IU; vitamin E, 40 IU; vitamin $\mathrm{K}_{3}$, $4 \mathrm{mg}$; vitamin $\mathrm{B}_{1}, 6 \mathrm{mg}$; vitamin $\mathrm{B}_{2}, 12 \mathrm{mg}$; vitamin $\mathrm{B}_{6}, 6 \mathrm{mg}$; vitamin $\mathrm{B}_{12}, 0.05 \mathrm{mg}$; biotin, 0.2 $\mathrm{mg}$; folic acid, $2 \mathrm{mg}$; niacin, $50 \mathrm{mg}$; D-calcium pantothenate, $25 \mathrm{mg}$; Fe,100 mg as ferrous sulfate; $\mathrm{Cu}, 150$ mg as copper sulphate; Mn, $40 \mathrm{mg}$ as manganese oxide; $\mathrm{Zn}, 100 \mathrm{mg}$ as zinc oxide; I, $0.5 \mathrm{mg}$ as potassium iodide; and Se, $0.3 \mathrm{mg}$ as sodium selenite. The values are expressed as percentage (\%), except for 
digestible energy (DE; MJ/kg), essential amino acid (EAA)/nonessential amino acid (NEAA). ${ }^{c T h e}$ DE was calculated according to NRC (2012). 'All other values represent analyzed values.

Table 2. Feedstuff ingredients and nutrient composition in experimental diets for 30- to $45-\mathrm{kg}$ growing pigs (\%).

\begin{tabular}{|c|c|c|c|}
\hline \multirow{2}{*}{ Feed ingredient } & \multicolumn{3}{|c|}{ CP levels ${ }^{a}$} \\
\hline & $12 \% \mathrm{CP}$ & $15 \% \mathrm{CP}$ & $18 \% \mathrm{CP}$ \\
\hline Corn $(43 \% \mathrm{CP})$ & 77.60 & 67.50 & 58.60 \\
\hline Soybean meal & 10.00 & 19.50 & 29.00 \\
\hline Wheat bran & 5.06 & 6.94 & 7.80 \\
\hline Soybean oil & 3.00 & 2.38 & 1.55 \\
\hline Lysine hydrochloride & 0.74 & 0.46 & 0.18 \\
\hline Hydroxy methionine & 0.17 & 0.09 & 0.00 \\
\hline L-threonine & 0.26 & 0.14 & 0.01 \\
\hline L-tryptophan & 0.07 & 0.02 & 0.00 \\
\hline CaHPO3 & 0.90 & 0.78 & 0.69 \\
\hline Rock-powder & 0.90 & 0.89 & 0.87 \\
\hline Salt & 0.30 & 0.30 & 0.30 \\
\hline $1 \%$ Premix $^{b}$ & 1.00 & 1.00 & 1.00 \\
\hline Total & 100.00 & 100.00 & 100.00 \\
\hline \multicolumn{4}{|c|}{ Calculated and analyzed nutrient composition ${ }^{\mathrm{c}}$} \\
\hline $\mathrm{DE}(\mathrm{MJ} / \mathrm{kg})$ & 14.20 & 14.20 & 14.20 \\
\hline $\mathrm{CP}$ & 12.35 & 15.16 & 18.27 \\
\hline Total Ca & 0.61 & 0.63 & 0.60 \\
\hline Total P & 0.45 & 0.48 & 0.51 \\
\hline Starch & 49.87 & 44.16 & 38.96 \\
\hline $\mathrm{NDF}$ & 10.09 & 11.09 & 11.87 \\
\hline $\mathrm{ADF}$ & 3.53 & 4.14 & 4.68 \\
\hline Lys & 0.94 & 0.97 & 0.97 \\
\hline Met + Cys & 0.55 & 0.56 & 0.57 \\
\hline Thr & 0.60 & 0.61 & 0.61 \\
\hline $\operatorname{Trp}$ & 0.17 & 0.17 & 0.17 \\
\hline Arg & 0.57 & 0.82 & 1.08 \\
\hline His & 0.25 & 0.33 & 0.41 \\
\hline Ile & 0.35 & 0.49 & 0.64 \\
\hline Leu & 0.94 & 1.14 & 1.35 \\
\hline Phe & 0.46 & 0.62 & 0.77 \\
\hline Val & 0.44 & 0.56 & 0.66 \\
\hline
\end{tabular}

aDiet treatment: Crude protein (CP) levels contain $12 \%, 15 \%$ and $18 \%$, respectively and supplementation with appropriate crystalline AA. bremix provided these amounts of vitamins and minerals per kilogram on an as-fed basis: vitamin A, 10,800 IU; vitamin $\mathrm{D}_{3}, 4,000 \mathrm{IU}$; vitamin E, 40 IU; vitamin $\mathrm{K}_{3}, 4 \mathrm{mg}$; vitamin $\mathrm{B}_{1}, 6 \mathrm{mg}$; vitamin $\mathrm{B}_{2}, 12 \mathrm{mg}$; vitamin $\mathrm{B}_{6}, 6 \mathrm{mg}$; vitamin $\mathrm{B}_{12}, 0.05 \mathrm{mg}$; biotin, 0.2 $\mathrm{mg}$; folic acid, $2 \mathrm{mg}$; niacin, $50 \mathrm{mg}$; D-calcium pantothenate, $25 \mathrm{mg}$; Fe,100 mg as ferrous sulfate; $\mathrm{Cu}, 150$ $\mathrm{mg}$ as copper sulphate; Mn, $40 \mathrm{mg}$ as manganese oxide; $\mathrm{Zn}, 100 \mathrm{mg}$ as zinc oxide; I, $0.5 \mathrm{mg}$ as potassium iodide; and Se, $0.3 \mathrm{mg}$ as sodium selenite. The values are expressed as percentage (\%), except for digestible energy (DE; MJ/kg), essential amino acid (EAA)/nonessential amino acid (NEAA). ${ }^{\mathrm{T} T h e}$ DE was calculated according to NRC (2012). 'All other values represent analyzed values. 
Table 3. Feedstuff ingredients and nutrient composition in experimental diets for $45-$ to $80-\mathrm{kg}$ finishing pigs (\%).

\begin{tabular}{|c|c|c|c|}
\hline \multirow{2}{*}{ Feed ingredient } & \multicolumn{3}{|c|}{ CP levels ${ }^{a}$} \\
\hline & $10 \% \mathrm{CP}$ & $13 \% \mathrm{CP}$ & $16 \% \mathrm{CP}$ \\
\hline Corn $(43 \% \mathrm{CP})$ & 87.40 & 78.36 & 67.00 \\
\hline Soybean meal & 5.50 & 15.00 & 23.76 \\
\hline Wheat bran & 2.00 & 3.00 & 6.00 \\
\hline Soybean oil & 1.71 & 0.90 & 0.88 \\
\hline Lysine hydrochloride & 0.55 & 0.27 & 0.01 \\
\hline Hydroxy methionine & 0.09 & 0.00 & 0.00 \\
\hline L- threonine & 0.19 & 0.06 & 0.00 \\
\hline L-tryptophan & 0.06 & 0.01 & 0.00 \\
\hline СaHPO3 & 0.65 & 0.55 & 0.50 \\
\hline Rock-powder & 0.55 & 0.55 & 0.55 \\
\hline Salt & 0.30 & 0.30 & 0.30 \\
\hline $1 \%$ Premix $^{b}$ & 1.00 & 1.00 & 1.00 \\
\hline Total & 100.00 & 100.00 & 100.00 \\
\hline \multicolumn{4}{|c|}{ Calculated and analyzed nutrient compositionc } \\
\hline $\mathrm{DE}(\mathrm{MJ} / \mathrm{kg})$ & 14.20 & 14.20 & 14.20 \\
\hline $\mathrm{CP}$ & 10.26 & 13.17 & 16.30 \\
\hline Total Ca & 0.51 & 0.50 & 0.52 \\
\hline Total P & 0.38 & 0.40 & 0.45 \\
\hline Starch & 55.22 & 49.97 & 43.71 \\
\hline $\mathrm{NDF}$ & 9.37 & 10.18 & 11.33 \\
\hline $\mathrm{ADF}$ & 3.14 & 3.69 & 4.34 \\
\hline Lys & 0.73 & 0.72 & 0.72 \\
\hline Met + Cys & 0.43 & 0.42 & 0.50 \\
\hline Thr & 0.49 & 0.50 & 0.56 \\
\hline $\operatorname{Trp}$ & 0.13 & 0.13 & 0.17 \\
\hline Arg & 0.44 & 0.70 & 0.94 \\
\hline His & 0.22 & 0.31 & 0.39 \\
\hline Ile & 0.30 & 0.45 & 0.60 \\
\hline Leu & 0.91 & 1.13 & 1.32 \\
\hline Phe & 0.41 & 0.57 & 0.71 \\
\hline Val & 0.36 & 0.50 & 0.61 \\
\hline
\end{tabular}

aDiet treatment: Crude protein (CP) levels contain $10 \%, 13 \%$ and $16 \%$, respectively and

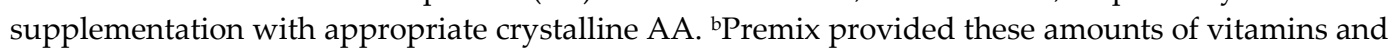
minerals per kilogram on an as-fed basis: vitamin A, 10,800 IU; vitamin D3, 4,000 IU; vitamin E, 40 IU; vitamin $\mathrm{K}_{3}, 4 \mathrm{mg}$; vitamin $\mathrm{B}_{1}, 6 \mathrm{mg}$; vitamin $\mathrm{B}_{2}, 12 \mathrm{mg}$; vitamin $\mathrm{B}_{6}, 6 \mathrm{mg}$; vitamin $\mathrm{B}_{12}, 0.05 \mathrm{mg}$; biotin, 0.2 $\mathrm{mg}$; folic acid, $2 \mathrm{mg}$; niacin, $50 \mathrm{mg}$; D-calcium pantothenate, $25 \mathrm{mg}$; Fe,100 mg as ferrous sulfate; $\mathrm{Cu}, 150$ mg as copper sulphate; Mn, $40 \mathrm{mg}$ as manganese oxide; $\mathrm{Zn}, 100 \mathrm{mg}$ as zinc oxide; I, $0.5 \mathrm{mg}$ as potassium

iodide; and Se, $0.3 \mathrm{mg}$ as sodium selenite. The values are expressed as percentage (\%), except for digestible energy (DE; MJ/kg), essential amino acid (EAA)/nonessential amino acid (NEAA). cThe DE was calculated according to NRC (2012). 'All other values represent analyzed values.

\section{$2.7 \mathrm{~N}$ balance}

The $\mathrm{N}$ balance experiment was maintained for seven days. During the 3-day collection period, pigs were placed in metabolism cages, and all of their fresh feces and urine were collected as previously described [18]. Fresh urine was collected in a plastic cask containing $30 \mathrm{~mL}$ of $6 \mathrm{~mol} / \mathrm{L}$ $\mathrm{HCl}$, and a $50-\mathrm{mL}$ aliquot of fresh urine was stored daily at $4 \mathrm{oC}$ until the end of the experiment and was subsequently frozen at $20 \mathrm{oC}$ for further analyses. TiQ2 $(1 \mathrm{~g} / \mathrm{kg}$ diet $)$ was used as an inert marker 
to identify feces from the initial diet during the collection period as previously described [15]. At the end of the experiment, all of the fresh feces were desiccated in a 55oC air-forced drying oven. The feces were sub-sampled and ground through a 1-mm screen, then weighed and stored in plastic bags. All of the feces and urine samples were analyzed for $\mathrm{N}$ as previously described [15]. The apparent $\mathrm{N}$ balance and other $\mathrm{N}$ balance items were calculated as the difference between consumption and excretion.

Table 4. Primers used for real-time PCR analysis.

\begin{tabular}{ccc}
\hline Target gene & Primer sequence & Accession NO. \\
\hline Trypsinogen & Sense 5'-AGCAATTCATCAATGCCGCC-3' & NM_001162891.1 \\
& Antisense 5'-CAGGAGCGAAGGGTAGCTG-3' & \\
Pancreatic $\alpha$-Amylase 2A & Sense 5'-TAAGCACATGTGGCCTGGAG-3' & XM_001929136.5 \\
& Antisense 5'-AAGGGCTCTATCAGAGGGCA-3' & \\
Pancreatic carboxypeptidase B1 & Sense 5'-AGGTGAGAAGGTGTTCCGTG-3' & NM_214169.1 \\
& Antisense 5'-TGCGAGAGATGAGGTCTGGA-3' & \\
Duodenal enterokinase & Sense 5'-TCTCCATACGGAGGAAGCCA-3' & XM_005668172.1 \\
Chymotrypsin B & Antisense 5'-TGGGCCAGTCATCCCATTTC-3' & \\
Chymotrypsin C & Sense 5'-AACAGGCTTCCACTACTGCG-3' & XM_003472038.1 \\
& Antisense 5'-TGGTCAGTAGCAAAGGGCAG-3' & \\
Pancreatic $\alpha$-amylase 2B & Sense 5'-GCGGCACCTTAATCACCTCT-3' & NM_001244379.1 \\
& Antisense 5'-GGCAGGCATAACACCTGGAT-3' & \\
Pancrelipase & Sense 5'-TGCTCTTGAATGTGAGCGGT-3' & NM_214195.1 \\
& Antisense 5'-TACGGACGCCAACGTTGTTA-3' & \\
Jejunal maltase & Sense 5'-AAGGTGGAGAGCGTGAACTG-3' & NM_001177912.2 \\
& Antisense 5'-TCCAGCCCTGTGATTCGTTC-3' & \\
Jejunal sucrase & Sense 5'-GCACAGATCAGCCGATGAGA-3' & XM_005657730.1 \\
& Antisense 5'-CAAATGACCGTCCAGCTCCT-3' & \\
& Sense 5'-TGGTGGCACTGTTATCCGAC-3' & XM_005657098.1 \\
& Antisense 5'-GAGCAGGCTCTTGACATGGT-3' & \\
& Sense 5'-TGTGGCAGATCACTTCGACC-3' & XM_003355779.3 \\
& Antisense 5'-CTCTTCCTCACTCCAGCCAC-3' & \\
\hline & &
\end{tabular}

\subsection{Analysis of conventional items}

All samples of ideal digesta were pooled and homogenized in a blender, sub-sampled, and freeze-dried, then finely ground in grinder, and thoroughly mixed for analysis as previously described [2]. All samples and nine diets were analyzed for conventional items, such as DM, DE, N and concentrations of AA. DM was analyzed using an AOAC protocol (1990; method 925.09)[19], and gross energy (GE) was analyzed using an oxygen bomb calorimeter as previously described $[2,20]$. The $\mathrm{N}$ was analyzed using a previously described method [2]. Samples of AA determination were prepared with acid hydrolysis using a previously described protocol [2]. The tryptophan was not analyzed because it was destroyed during the preparation with acid hydrolysis[21].

\subsection{Relative Quantification PCR analysis of gene expression levels for digestive enzymes}

The software program (Primer 5.0; Primer-E Ltd., Plymouth, UK) was used to design primers, which are listed in Table 4 . The $\beta$-actin gene was used as an internal control to normalize expression of target gene transcript levels. Total intestine tissue RNA was isolated using TRIzol regent (Invitrogen, Carlsbad, CA, USA) as previously described [22,23]. The cDNA was reverse transcribed and amplified by quantitative real-time PCR using the ABI 7900 PCR system (ABI Biotechnology, Eldersburg, MD, USA) as previously described [22,23]. Each sample had a total volume of $10 \mu \mathrm{L}$, 
including $1 \mu \mathrm{L}$ of 4 times diluted cDNA, $5 \mu \mathrm{L}$ SYBR Green mix, $0.2 \mu \mathrm{L}$ ROX Reference Dye (50 times), and $0.2 \mu \mathrm{L}$ each of forward and reverse primers. After predenaturation (10s at $95 \mathrm{oC}), 40$ cycles of amplification were performed, and each cycle consisted of $95 \mathrm{oC}$ for $5 \mathrm{~s}$, and $60 \mathrm{oC}$ for $20 \mathrm{~s}$, followed by a melting curve program $\left(60^{\circ} \mathrm{C}\right.$ to $99^{\circ} \mathrm{C}$ with a heating rate of $0.1^{\circ} \mathrm{C} / \mathrm{s}$ and fluorescence measurement). The relative levels of genes were expressed as a ratio of mRNA as $R=2-(\Delta \mathrm{C} t)$. The efficiency of real-time PCR was determined by amplification of a dilution series of cDNA according to equation $10(-1 /$ slope $)$, and the results for target mRNA were consistent with the targets for $\beta$-actin. Negative controls were created by replacing cDNA with water.

\subsection{Statistical analysis}

All results are expressed as the mean \pm standard error of the mean (SEM). Statistical analyses were subjected to one-way analysis of variance in the SAS 8.2 software program (Version 8.2; SAS Inst. Inc., Cary, NC). The differences among group means were compared using the Duncan multiple comparison test. Probability values $<0.05$ were used to indicate statistical significance.

\section{Results}

\subsection{Dynamics affect growth performance}

As shown in Table 5, growing pigs fed the $14 \% \mathrm{CP}$ and $17 \% \mathrm{CP}$ diets had a lower final BW (P< $0.05)$ and ADG $(\mathrm{P}<0.05)$ compared to pigs fed a $20 \% \mathrm{CP}$ diet in Experiment 1 . Growing pigs fed the control diet $(20 \% \mathrm{CP})$ had no difference for $\mathrm{F}$ : $\mathrm{G}$ compared to $14 \% \mathrm{CP}$ and $17 \% \mathrm{CP}$ diets $(\mathrm{P}>0.05)$. However, the ADFI of growing pigs was not affected (P > 0.05) after feeding $14 \% \mathrm{CP}, 17 \% \mathrm{CP}$, and $20 \%$ $\mathrm{CP}$ diets. In Experiment 2, growing pigs fed the control diet $(18 \% \mathrm{CP})$ had no differences in final $\mathrm{BW}$ $(P>0.05)$, ADG $(P>0.05)$, ADFI $(P>0.05)$, and F: $G(P>0.05)$ among animals that were fed $12 \% \mathrm{CP}$, $15 \% \mathrm{CP}$, and $18 \% \mathrm{CP}$ diets. In Experiment 3, the finishing pigs fed the control diet $(16 \% \mathrm{CP})$ had no differences in final BW $(P>0.05)$, ADG $(P>0.05)$, ADFI $(P>0.05)$, and $F: G(P>0.05)$ among animals fed the $10 \% \mathrm{CP}, 13 \% \mathrm{CP}$, and $16 \% \mathrm{CP}$ diets. Significantly different effects are clearly shown in Experiment 1, and there was a slightly higher value compared to the control (Group C) for ADG, ADFI, and F: $G$ in Experiment 3.

Table 5. Dynamics alterations of low-protein diets affect growth performance for growing and finishing pigs.

\begin{tabular}{|c|c|c|c|c|c|}
\hline Items & Group A & Group B & Group C & P value & SEM \pm \\
\hline \multicolumn{6}{|c|}{ Growing pigs (Experiment 15) } \\
\hline Initial $\mathrm{BW}^{1}, \mathrm{~kg}$ & 9.51 & 9.51 & 9.52 & 0.00 & 1.00 \\
\hline Final BW, kg & $27.71^{\mathrm{b}}$ & $29.29 \mathrm{ab}$ & $30.36^{a}$ & 0.03 & 0.77 \\
\hline $\mathrm{ADG}^{2}, \mathrm{~g} / \mathrm{d}$ & $404.45^{\mathrm{b}}$ & $439.55^{\mathrm{ab}}$ & $463.1^{\mathrm{a}}$ & 0.02 & 17.04 \\
\hline $\mathrm{ADFI}^{3}, \mathrm{~g} / \mathrm{d}$ & $690.55^{\mathrm{b}}$ & $736.4^{\mathrm{ab}}$ & $775.8 \mathrm{a}$ & 0.06 & 24.63 \\
\hline $\mathrm{F}: \mathrm{G}^{4}$ & 1.71 & 1.68 & 1.68 & 0.94 & 0.01 \\
\hline \multicolumn{6}{|c|}{ Growing pigs (Experiment 26) } \\
\hline Initial BW, kg & $27.71^{b}$ & $29.29 \mathrm{ab}$ & $30.36^{\mathrm{a}}$ & 0.03 & 0.77 \\
\hline Final BW, kg & 43.07 & 45.37 & 45.77 & 0.22 & 0.84 \\
\hline $\mathrm{ADG}, \mathrm{g} / \mathrm{d}$ & 448.3 & 478.5 & 483.8 & 0.23 & 11.06 \\
\hline ADFI, g/d & 1291 & 1359 & 1379 & 0.26 & 26.63 \\
\hline$F: G$ & 2.88 & 2.84 & 2.85 & 0.92 & 0.01 \\
\hline \multicolumn{6}{|c|}{ Finishing pigs (Experiment $3^{7}$ ) } \\
\hline Initial BW, kg & 43.07 & 45.37 & 45.77 & 0.22 & 0.84 \\
\hline Final BW, kg & 84.22 & 82.78 & 82.38 & 0.40 & 0.56 \\
\hline $\mathrm{ADG}, \mathrm{g} / \mathrm{d}$ & 598.3 & 586.5 & 583.3 & 0.90 & 4.56 \\
\hline ADFI, g/d & 2196 & 2170 & 2164 & 0.96 & 9.82 \\
\hline $\mathrm{F}: \mathrm{G}$ & 3.67 & 3.7 & 3.71 & 0.93 & 0.01 \\
\hline
\end{tabular}

Data are means with the pooled means \pm standard error of the mean (SEM), $n=6$ /treatment group. Within a row, values with different superscript letters differ $(\mathrm{P}<0.05) .{ }^{1} \mathrm{BW}$, body weight; ${ }^{2} \mathrm{ADG}$, average 
daily gain; ${ }^{3} \mathrm{ADFI}$, average daily feed intake; ${ }^{4 \mathrm{~F}} \mathrm{G}$, the ratio of feed and gain. $\mathrm{CP}=$ crude protein. ${ }^{5}$ Experiment 1: Group A = $14 \%$ CP (very low CP level); Group B = $17 \%$ CP (low CP level); Group C $=20 \%$ $\mathrm{CP}$ (normal CP level). Groups A and B were supplemented with L-lysine, L-methionine, L-threonine, and L-tryptophan (see Table 1). ${ }^{6}$ Experiment 2: Group A $=12 \% \mathrm{CP}$ (very low $\mathrm{CP}$ level); Group B $=15 \%$

CP (low CP level); Group C = 18\% CP (normal CP level). Groups A and B were supplemented with L-lysine, L-methionine, L-threonine, and L-tryptophan (see Table 2). ${ }^{7}$ Experiment 3: Group A $=10 \% \mathrm{CP}$ (very low CP level); Group B = 13\% CP (low CP level); Group C =16\% CP (normal CP level). Groups A and B were supplemented with L-lysine, L-methionine, L-threonine, and L-tryptophan (see Table 3).

\subsection{Dynamics affect $N$ balance}

As shown in Table 6, a reduction in dietary CP levels from $20 \%$ to $14 \%$ in growing pigs resulted in a significant decrease in $\mathrm{N}$ intake $(\mathrm{P}<0.01)$, urinary $\mathrm{N}$ excretion $(\mathrm{P}<0.01)$, total $\mathrm{N}$ excretion $(\mathrm{P}<$ $0.01)$ and relatively reduced $\mathrm{N}$ excretion $(\mathrm{P}<0.01)$. There was also significantly increased $\mathrm{N}$ net utilization $(\mathrm{P}<0.01)$ and apparent biological value $(\mathrm{P}<0.05)$. There was no difference in fecal $\mathrm{N}$ excretion $(\mathrm{P}>0.05)$, apparent $\mathrm{N}$ digestibility $(\mathrm{P}>0.05)$ and $\mathrm{N}$ retained $(\mathrm{P}>0.05)$ in Experiment 1.

Reduction in dietary $\mathrm{CP}$ levels from $18 \%$ to $12 \%$ in growing pigs resulted in a significant decrease in $\mathrm{N}$ intake $(\mathrm{P}<0.01)$, urinary $\mathrm{N}$ excretion $(\mathrm{P}<0.01)$, fecal $\mathrm{N}$ excretion $(\mathrm{P}<0.05)$, total $\mathrm{N}$ excretion $(\mathrm{P}<0.01)$, relatively reduced $\mathrm{N}$ excretion $(\mathrm{P}<0.01)$, apparent $\mathrm{N}$ net utilization $(\mathrm{P}<0.01)$ and $\mathrm{N}$ retention $(\mathrm{P}<0.05)$. There was also a significantly increased apparent biological value $(\mathrm{P}<$ 0.05 ) in Experiment 2 (Table 6). There was no difference in apparent $\mathrm{N}$ digestibility $(\mathrm{P}>0.05)$ in Experiment 2.

Reduction in dietary CP levels from $16 \%$ to $10 \%$ in finishing pigs resulted in significantly decreased $\mathrm{N}$ intake $(\mathrm{P}<0.01)$, urinary $\mathrm{N}$ excretion $(\mathrm{P}<0.01)$, fecal $\mathrm{N}$ excretion $(\mathrm{P}<0.05)$, total $\mathrm{N}$ excretion $(\mathrm{P}<0.01)$, relatively reduced $\mathrm{N}$ excretion $(\mathrm{P}<0.01)$, apparent $\mathrm{N}$ net utilization $(\mathrm{P}<0.01)$ and $\mathrm{N}$ retained $(\mathrm{P}<0.01)$. There was also significantly increased apparent biological value $(\mathrm{P}<0.05)$ in Experiment 3 (Table 6). There was no difference in apparent $\mathrm{N}$ digestibility $(\mathrm{P}>0.05)$ in Experiment 3.

\subsection{Dynamics affect ileal digestibility}

As shown in Table 7, the low $\mathrm{CP}$ diet had no effect $(\mathrm{P}>0.05)$ on its DE and DM from Experiment 1 to Experiment 3. In Experiment 1, growing pigs fed the $14 \% \mathrm{CP}$ diet showed higher digestibility of CP $(\mathrm{P}<0.05)$, Arg $(\mathrm{P}<0.001)$, His $(\mathrm{P}<0.05)$, Ile $(\mathrm{P}<0.05)$, Lys $(\mathrm{P}<0.001)$, Met $(\mathrm{P}<0.05)$, Phe $(\mathrm{P}<0.05)$, Thr $(\mathrm{P}<0.05)$, Trp $(\mathrm{P}<0.05)$, Val $(\mathrm{P}<0.05)$, Asp $(\mathrm{P}<0.05)$, Glu $(\mathrm{P}<0.05)$, Pro $(\mathrm{P}<0.05)$, and Ser $(\mathrm{P}<$ 0.05 ) compared to pigs fed the $20 \% \mathrm{CP}$ diet (Table 7). Lys digestibility increased $(\mathrm{P}<0.001)$ from $77.45 \%$ in growing pigs fed the $20 \% \mathrm{CP}$ diets to $87.7 \%$ in growing pigs fed the $14 \% \mathrm{CP}$ diet. Similar results were obtained for Arg. There were no differences $(P>0.05)$ in the digestibility of other AA among the three groups of finishing pigs (Table 7).

In Experiment 2, growing pigs fed the $12 \% \mathrm{CP}$ diet showed higher digestibility of $\mathrm{CP}(\mathrm{P}<0.05)$, His $(\mathrm{P}<0.05)$, Ile $(\mathrm{P}<0.05)$, Lys $(\mathrm{P}<0.05)$, Met $(\mathrm{P}<0.001)$, Cys $(\mathrm{P}<0.001)$, Phe $(\mathrm{P}<0.05)$, Thr $(\mathrm{P}<0.05)$, $\operatorname{Trp}(\mathrm{P}<0.05)$, Gly $(\mathrm{P}<0.05)$, and Ser $(\mathrm{P}<0.05)$ compared to pigs fed the $18 \% \mathrm{CP}$ diet (Table 7$)$. Met digestibility increased $(\mathrm{P}<0.001)$ from $70.48 \%$ in growing pigs fed the $18 \% \mathrm{CP}$ diet to $80.42 \%$ in growing pigs fed the $12 \% \mathrm{CP}$ diet. Similar results were obtained for Cys. There were no differences $(P>0.05)$ in the digestibility of other AA among the three groups of finishing pigs (Table 7).

Results for ileal AA digistibility in finishing pigs (Experiment 3) had a similar tendency in Table 7. Finishing pigs fed the $10 \% \mathrm{CP}$ diet showed higher digestibility of $\mathrm{CP}(\mathrm{P}<0.05)$, $\operatorname{Arg}(\mathrm{P}<0.05)$, His $(\mathrm{P}<0.05)$, Ile $(\mathrm{P}<0.05)$, Lys $(\mathrm{P}<0.001)$, Met $(\mathrm{P}<0.05)$, Phe $(\mathrm{P}<0.05)$, Thr $(\mathrm{P}<0.05)$, Trp $(\mathrm{P}<0.05)$, Gly $(\mathrm{P}<0.05)$, and Ser $(\mathrm{P}<0.05)$ compared to pigs fed the $16 \% \mathrm{CP}$ diet (Table 7$)$. Lys digestibility increased $(\mathrm{P}<0.001)$ from $77.54 \%$ in finishing pigs fed the $16 \% \mathrm{CP}$ diets to $87.91 \%$ in finishing pigs fed the $10 \% \mathrm{CP}$ diet. There were no differences $(\mathrm{P}>0.05)$ in the digestibility of other AA among the three groups of finishing pigs (Table 7). 
Table 6. Dynamics alterations of low-protein diets affect nitrogen balance for growing and finishing pigs.

\begin{tabular}{|c|c|c|c|c|c|}
\hline Items & Group A & Group B & Group C & P value & SEM \pm \\
\hline \multicolumn{6}{|l|}{ Growing pigs (Experiment $1^{6}$ ) } \\
\hline $\mathrm{N}$ intake $(\mathrm{g} / \mathrm{d})$ & $23.59^{\mathrm{b}}$ & $26.76^{\mathrm{ab}}$ & $29.47^{a}$ & 0.01 & 1.70 \\
\hline Urinary $\mathrm{N}$ excretion, $(\mathrm{g} / \mathrm{d})$ & $4.85^{\mathrm{b}}$ & $6.78^{\mathrm{b}}$ & $10.27^{a}$ & $<0.00$ & 1.59 \\
\hline Fecal N excretion, $(\mathrm{g} / \mathrm{d})$ & 2.61 & 3.72 & 4.06 & 0.11 & 0.44 \\
\hline Total N excretion ${ }^{1},(\mathrm{~g} / \mathrm{d})$ & $7.46^{c}$ & $10.5^{\mathrm{b}}$ & $14.33^{\mathrm{a}}$ & $<0.00$ & 1.99 \\
\hline Relative reduced of $\mathrm{N}$ excretion ${ }^{2},(\%)$ & $47.94^{\mathrm{a}}$ & $26.73^{b}$ & $100^{c}$ & $<0.0001$ & 6.14 \\
\hline N Retained ${ }^{3},(\mathrm{~g} / \mathrm{d})$ & 16.13 & 16.26 & 15.14 & 0.43 & 0.35 \\
\hline N net utilization ${ }^{9}(\%)$ & $68.38^{\mathrm{a}}$ & $60.76^{a}$ & $51.37^{\mathrm{b}}$ & 0.00 & 4.92 \\
\hline Apparent $\mathrm{N}$ digestibility ${ }^{4},(\%)$ & 88.94 & 86.1 & 86.22 & 0.67 & 0.93 \\
\hline Apparent biological value ${ }^{5}(\%)$ & $76.88^{\mathrm{a}}$ & $70.57 \mathrm{ab}$ & $59.58^{\mathrm{b}}$ & 0.01 & 5.05 \\
\hline \multicolumn{6}{|l|}{ Growing pigs (Experiment $2^{7}$ ) } \\
\hline $\mathrm{N}$ intake, $(\mathrm{g} / \mathrm{d})$ & 27.51 & 34.03 & 39.95 & $<0.00$ & 3.59 \\
\hline Urinary $\mathrm{N}$ excretion, $(\mathrm{g} / \mathrm{d})$ & 5.03 & 7.62 & 11.25 & $<0.00$ & 1.8 \\
\hline Fecal N excretion, $(\mathrm{g} / \mathrm{d})$ & $4.09 \mathrm{~b}$ & $5.19 \mathrm{ab}$ & $6.18^{\mathrm{a}}$ & 0.03 & 0.6 \\
\hline Total $N$ excretion, $(\mathrm{g} / \mathrm{d})$ & $9.12^{\mathrm{c}}$ & $12.81^{\mathrm{b}}$ & $17.43^{a}$ & $<0.00$ & 2.4 \\
\hline Relative reduced of $\mathrm{N}$ excretion, (\%) & $47.68^{\mathrm{a}}$ & $26.51^{b}$ & $100^{c}$ & $<0.00$ & 4.37 \\
\hline N Retained, $(\mathrm{g} / \mathrm{d})$ & $18.3^{\mathrm{b}}$ & $21.22^{\mathrm{a}}$ & $22.52^{\mathrm{a}}$ & 0.01 & 1.22 \\
\hline $\mathrm{N}$ net utilization, $(\%)$ & $66.85^{a}$ & $62.36^{\mathrm{ab}}$ & $56.37 \mathrm{~b}$ & 0.05 & 3.04 \\
\hline Apparent $\mathrm{N}$ digestibility, (\%) & 85.13 & 84.75 & 84.53 & 0.98 & 0.18 \\
\hline Apparent biological value, $(\%)$ & $78.52^{a}$ & $73.58^{\mathrm{ab}}$ & $66.69^{b}$ & 0.01 & 3.43 \\
\hline \multicolumn{6}{|l|}{ Finishing pigs (Experiment $3^{8}$ ) } \\
\hline N intake, $(\mathrm{g} / \mathrm{d})$ & $47.95^{c}$ & $60.82^{b}$ & $74.42^{\mathrm{a}}$ & $<0.00$ & 7.64 \\
\hline Urinary $\mathrm{N}$ excretion, (g/d) & $9.15^{c}$ & $15.42^{b}$ & $20.97 \mathrm{a}$ & $<0.00$ & 3.41 \\
\hline Fecal N excretion, $(\mathrm{g} / \mathrm{d})$ & $5.94^{\mathrm{b}}$ & $9.04^{\mathrm{a}}$ & $11.22^{\mathrm{a}}$ & 0.00 & 1.53 \\
\hline Total $\mathrm{N}$ excretion, $(\mathrm{g} / \mathrm{d})$ & $15.09^{c}$ & $24.46^{\mathrm{b}}$ & $32.19 \mathrm{a}$ & $<0.00$ & 4.94 \\
\hline Relative reduced of $\mathrm{N}$ excretion, (\%) & 53.12 & 24.01 & 100 & $<0.00$ & 8.01 \\
\hline N Retained, (g/d) & $32.86^{\mathrm{b}}$ & $36.36^{b}$ & $42.23^{a}$ & 0.00 & 2.73 \\
\hline N net utilization, $(\%)$ & $68.53^{\mathrm{a}}$ & $59.78^{b}$ & $56.74^{\mathrm{b}}$ & 0.00 & 3.53 \\
\hline Apparent $\mathrm{N}$ digestibility, (\%) & 87.61 & 85.14 & 84.92 & 0.48 & 0.86 \\
\hline
\end{tabular}


Apparent biological value, (\%)

$78.22^{\mathrm{a}}$

$70.22^{\mathrm{ab}}$

$66.82^{\mathrm{b}}$

0.02

Data are means with the pooled means \pm standard error of the mean (SEM), $n=6 /$ treatment group. Within a row, values with different superscript letters differ $(\mathrm{P}<0.05)$. The average initial weight for the four periods was showed in Table 4 . Each period was $7 \mathrm{~d}(28 \mathrm{~d}$ total $)$. 1Total $\mathrm{N}$ excretion $=$ urinary $\mathrm{N}$ excretion + fecal $\mathrm{N}$ excretion; 2Relative reduced of $\mathrm{N}$ excretion $=\mathrm{N}$ excretion of Group A (or Group B) $/ \mathrm{N}$ excretion of Group C $\times 100$, the $\mathrm{N}$ excretion value of Group C (normal crude protein (CP) level) was set to $100 \% ; 3 \mathrm{~N}$ Retained $=\mathrm{N}$ intake - $\mathrm{N}$ output; 4 Apparent $\mathrm{N}$ digestibility $=(\mathrm{N}$ absorbed $(\mathrm{N}$ absorbed $=\mathrm{N}$ intake - fecal $\mathrm{N}) \times 100) / \mathrm{N}$ intake; 5 Apparent biological value $=(\mathrm{N}$ intake- total $\mathrm{N}$ excretion $) /(\mathrm{N}$ intake- fecal $\mathrm{N}$ excretion); 6 Experiment 1: Group A = 14\% CP (very low CP level); Group B = 17\% CP (low CP level); Group C = 20\% CP (normal CP level).

Groups A and B were supplemented with L-lysine, L-methionine, L-threonine, and L-tryptophan (see Table 1). 7 Experiment 2: Group A = 12\% $\mathrm{CP}$ (very low CP level); Group B $=15 \%$ CP (low CP level); Group C = 18\% CP (normal CP level). Groups A and B were supplemented with

L-lysine, L-methionine, L-threonine, and L-tryptophan (see Table 2). 8 Experiment 3: Group A =10\% CP (very low CP level); Group B $=13 \% \mathrm{CP}$ (low CP level); Group C = 16\% CP (normal CP level). Groups A and B were supplemented with L-lysine, L-methionine, L-threonine, and L-tryptophan (see Table 3). ${ }^{9} \mathrm{~N}$ net utilization $=\mathrm{N}$ Retained/N intake $\times 100$. 


\subsection{Dynamic changes affect gene expression levels of digestive enzymes}

In Experiment 1, pigs fed the $14 \% \mathrm{CP}$ diet showed higher mRNA levels for pancreatic carboxypeptidase B1 ( $\mathrm{P}<0.01)$, chymotrypsin $\mathrm{C}(\mathrm{P}<0.01)$, and jejunal dipeptidase-II $(\mathrm{P}<0.05)$ compared to pigs fed the $20 \% \mathrm{CP}$ diet (Table 8). There were no differences in the expression levels of pancreatic carboxypeptidase B1, chymotrypsin C, or jejunal dipeptidase-II between the 14 and 17\% $\mathrm{CP}$ diet groups. The mRNA expression levels of trypsinogen, pancreatic $\alpha$-amylase 2A, duodenal enterokinase, chymotrypsin B, pancreatic $\alpha$-amylase 2B, jejunal maltase, and jejunal sucrose did not differ among the three groups of growing pigs $(P>0.05)$ (Table 8 ).

In Experiment 2, pigs fed the 12\% CP diet showed higher mRNA expression levels of duodenal enterokinase $(\mathrm{P}<0.05)$, chymotrypsin $\mathrm{B}(\mathrm{P}<0.01)$, and chymotrypsin $\mathrm{C}(\mathrm{P}<0.01)$ compared to pigs fed the $18 \%$ CP diet. The lowest mRNA expression levels of trypsinogen $(\mathrm{P}<0.05)$ and jejunal dipeptidase-II $(\mathrm{P}<0.05)$ occurred in pigs fed the $12 \% \mathrm{CP}$ diet (Table 8$)$. The mRNA expression levels of pancreatic $\alpha$-amylase 2B, pancrelipase, jejunal maltase, and jejunal sucrose did not differ among three groups of growing pigs $(\mathrm{P}>0.05)$.

In Experiment 3, pigs fed the $10 \% \mathrm{CP}$ diet showed lower mRNA expression levels of trypsinogen $(\mathrm{P}<0.05)$, chymotrypsin $\mathrm{C}(\mathrm{P}<0.05)$, and jejunal dipeptidase-II $(\mathrm{P}<0.05)$ compared to pigs fed the $16 \% \mathrm{CP}$ diet. The lowest mRNA expression levels of trypsinogen $(\mathrm{P}<0.05)$ occurred in pigs fed the $10 \% \mathrm{CP}$ diet. However, the highest value for chymotrypsin $\mathrm{B}(\mathrm{P}<0.05)$ occurred in pigs fed the $10 \%$ CP diet (Table 8). The mRNA expression levels of pancreatic $\alpha$-amylase 2A, pancreatic carboxypeptidase B1, duodenal enterokinase, pancreatic $\alpha$-amylase 2B, pancrelipase, jejunal maltase, and jejunal sucrose did not differ among the three groups of finishing pigs $(\mathrm{P}>0.05)$.

Table 7. Dynamics alterations of low-protein diets affect ileal digestibilities of DE, DM, and IDAA of growing

and finishing pigs.

\begin{tabular}{cccccc}
\hline Items & Group A & Group B & Group C & P value & SEM \pm \\
\hline \multicolumn{2}{c}{ Growing pigs (Experiment 11) } & & & & \\
\hline Energy & 86.08 & 84.02 & 83.24 & 0.21 & 0.93 \\
DM $^{2}$ & 80.4 & 82.4 & 81.1 & 0.20 & 0.89 \\
Protein & $92.51^{\mathrm{a}}$ & $88.86^{\mathrm{ab}}$ & $85.03^{\mathrm{b}}$ & 0.037 & 2.11 \\
Arg & $88.02^{\mathrm{a}}$ & $86.63^{\mathrm{a}}$ & $80.34^{\mathrm{b}}$ & $<0.001$ & 2.34 \\
His & $83.28^{\mathrm{a}}$ & $78.11^{\mathrm{b}}$ & $78.22^{\mathrm{b}}$ & 0.02 & 1.68 \\
Ile & $84.56^{\mathrm{a}}$ & $82.17^{\mathrm{ab}}$ & $77.18^{\mathrm{b}}$ & 0.01 & 1.88 \\
Leu & 83.78 & 80.26 & 80.73 & 0.30 & 2.41 \\
Lys & $87.70^{\mathrm{a}}$ & $82.23^{\mathrm{a}}$ & $77.45^{\mathrm{b}}$ & $<0.001$ & 3.54 \\
Met & $86.89^{\mathrm{a}}$ & $82.79^{\mathrm{ab}}$ & $80.25^{\mathrm{b}}$ & 0.03 & 1.53 \\
Cys & 84.03 & 83.68 & 80.22 & 0.14 & 1.47 \\
Phe & $83.87^{\mathrm{a}}$ & $81.56^{\mathrm{ab}}$ & $77.78^{\mathrm{b}}$ & 0.04 & 2.79 \\
Tyr & 87.28 & 85.75 & 84.79 & 0.51 & 2.19 \\
Thr & $80.53^{\mathrm{a}}$ & $77.15^{\mathrm{ab}}$ & $74.58^{\mathrm{b}}$ & 0.04 & 3.08 \\
Trp & $80.28^{\mathrm{a}}$ & $77.28^{\mathrm{ab}}$ & $73.57^{\mathrm{b}}$ & 0.02 & 1.86 \\
Val & $79.19^{\mathrm{a}}$ & $72.36^{\mathrm{b}}$ & $72.54^{\mathrm{b}}$ & 0.02 & 2.46 \\
Ala & 82.76 & 80.08 & 80.19 & 0.31 & 0.84 \\
Asp & $80.63^{\mathrm{a}}$ & $79.67^{\mathrm{ab}}$ & $74.27^{\mathrm{b}}$ & 0.02 & 2.77 \\
Glu & $87.59^{\mathrm{a}}$ & $86.71^{\mathrm{a}}$ & $80.64^{\mathrm{b}}$ & 0.02 & 1.97 \\
Gly & 77.61 & 76.48 & 74.40 & 0.54 & 1.06 \\
Pro & $76.42^{\mathrm{a}}$ & $72.38^{\mathrm{ab}}$ & $70.89^{\mathrm{b}}$ & 0.04 & 1.73 \\
Ser & $82.21^{\mathrm{a}}$ & $79.77^{\mathrm{ab}}$ & $75.52^{\mathrm{b}}$ & 0.01 & 3.73 \\
Growing pigs (Experiment 23) & & & & \\
\hline
\end{tabular}




\begin{tabular}{|c|c|c|c|c|c|}
\hline Energy & 85.62 & 86.82 & 85.23 & 0.69 & 0.48 \\
\hline $\mathrm{DM}$ & 84.43 & 83.78 & 82.15 & 0.31 & 0.68 \\
\hline Protein & $80.15^{\mathrm{a}}$ & $78.41^{\mathrm{ab}}$ & $76.53^{b}$ & 0.05 & 1.05 \\
\hline Arg & 85.36 & 85.65 & 84.27 & 0.78 & 0.42 \\
\hline His & $75.68^{a}$ & 73.73ab & $70.24^{b}$ & 0.02 & 1.59 \\
\hline Ile & $73.72 \mathrm{a}$ & $70.37 \mathrm{~b}$ & $69.66 b$ & 0.01 & 1.25 \\
\hline Leu & 73.38 & 72.25 & 71.34 & 0.58 & 0.59 \\
\hline Lys & $79.47^{a}$ & $75.26^{\mathrm{ab}}$ & $72.32^{b}$ & 0.01 & 2.07 \\
\hline Met & $80.42^{a}$ & $77.13^{a}$ & $70.48^{b}$ & $<0.001$ & 2.92 \\
\hline Cys & $81.63^{a}$ & 77.39ab & $72.36^{b}$ & $<0.001$ & 2.68 \\
\hline Phe & $79.38^{a}$ & 78.74ab & $73.79^{b}$ & 0.03 & 1.77 \\
\hline Tyr & 78.71 & 78.24 & 76.97 & 0.72 & 0.52 \\
\hline Thr & $79.35^{\mathrm{a}}$ & $75.2^{\mathrm{ab}}$ & $73.98^{b}$ & 0.02 & 1.63 \\
\hline $\operatorname{Trp}$ & $78.85^{a}$ & 75.27ab & $73.24^{b}$ & 0.01 & 1.64 \\
\hline Val & 74.83 & 73.68 & 72.94 & 0.66 & 0.55 \\
\hline Ala & 72.15 & 71.73 & 70.52 & 0.74 & 0.49 \\
\hline Asp & 84.97 & 85.14 & 82.76 & 0.53 & 0.77 \\
\hline Glu & 87.24 & 86.73 & 86.15 & 0.88 & 0.31 \\
\hline Gly & $78.36^{\mathrm{a}}$ & $75.21^{\mathrm{ab}}$ & $73.19^{b}$ & 0.02 & 1.50 \\
\hline Pro & 75.24 & 75.15 & 74.84 & 0.97 & 0.12 \\
\hline Ser & $77.69^{a}$ & $75.23^{\mathrm{ab}}$ & $73.97^{b}$ & 0.03 & 1.09 \\
\hline \multicolumn{6}{|c|}{ Finishing pigs (Experiment $3^{4}$ ) } \\
\hline Energy & 86.58 & 84.12 & 83.64 & 0.20 & 0.91 \\
\hline DM & 80.26 & 82.17 & 81.25 & 0.46 & 1.16 \\
\hline Protein & $81.74^{a}$ & $80.36^{a}$ & $76.95^{b}$ & 0.005 & 1.42 \\
\hline Arg & $88.52^{a}$ & $86.83^{a}$ & $80.64^{\mathrm{b}}$ & 0.01 & 2.40 \\
\hline His & $83.39^{a}$ & $78.23^{b}$ & $78.32^{\mathrm{b}}$ & 0.02 & 1.71 \\
\hline Ile & $84.78^{a}$ & $82.26^{\mathrm{ab}}$ & $78.21^{b}$ & 0.01 & 1.91 \\
\hline Leu & 83.89 & 80.37 & 80.89 & 0.29 & 2.09 \\
\hline Lys & $87.91^{\mathrm{a}}$ & $83.46^{a}$ & $77.54^{\mathrm{b}}$ & $<0.001$ & 3.60 \\
\hline Met & $87.73^{a}$ & $83.66^{\mathrm{ab}}$ & $80.1^{\mathrm{b}}$ & 0.04 & 1.64 \\
\hline Cys & 84.43 & 83.98 & 80.26 & 0.14 & 1.32 \\
\hline Phe & $83.91^{a}$ & $81.97^{\mathrm{ab}}$ & $77.95^{\mathrm{b}}$ & 0.03 & 2.89 \\
\hline Tyr & 87.54 & 85.85 & 84.86 & 0.40 & 2.24 \\
\hline Thr & $80.57^{a}$ & 77.27ab & $74.64^{\mathrm{b}}$ & 0.03 & 3.62 \\
\hline $\operatorname{Trp}$ & $80.46^{a}$ & $77.12^{\mathrm{ab}}$ & $73.63^{b}$ & 0.01 & 1.97 \\
\hline Val & $79.36^{\mathrm{a}}$ & $72.58^{\mathrm{b}}$ & $72.28^{b}$ & 0.01 & 2.31 \\
\hline Ala & 82.87 & 80.14 & 80.23 & 0.26 & 0.90 \\
\hline Asp & $80.96^{a}$ & $78.52^{\mathrm{ab}}$ & $74.22^{b}$ & 0.02 & 2.82 \\
\hline Glu & $87.67^{a}$ & $86.68^{a}$ & $80.88^{b}$ & 0.01 & 2.12 \\
\hline Gly & 77.52 & 76.54 & 74.43 & 0.52 & 0.91 \\
\hline Pro & $76.3^{a}$ & 72.47ab & $70.93^{b}$ & 0.04 & 1.60 \\
\hline Ser & $82.1^{\mathrm{a}}$ & $79.89^{\mathrm{ab}}$ & $75.72^{b}$ & 0.01 & 3.64 \\
\hline
\end{tabular}

Data are means with the pooled means \pm standard error of the mean (SEM), $n=6 /$ treatment group. Within a row, values with different superscript letters differ $(P<0.05)$. The average initial weight for the four periods was showed in Table $4 .{ }^{2} \mathrm{DM}=$ dry matter; $\mathrm{CP}=$ crude protein; IDAA = ileal digesta of amino acids; ${ }^{1}$ Experiment 1 : Group $\mathrm{A}=14 \% \mathrm{CP}$ (very low CP level); Group B $=17 \%$ CP (low CP level); Group C $=20 \%$ CP (normal CP level). Groups $\mathrm{A}$ and $\mathrm{B}$ were supplemented with L-lysine, L-methionine, L-threonine, and L-tryptophan (see Table 1). ${ }^{3}$ Experiment 2: Group A $=12 \% \mathrm{CP}$ (very low CP level); Group B $=15 \% \mathrm{CP}$ (low CP level); Group C $=18 \% \mathrm{CP}$ (normal CP level). Groups A and B were supplemented with L-lysine, L-methionine, L-threonine, and L-tryptophan (see Table 2). ${ }^{4}$ Experiment 3 : Group A $=10 \%$ CP (very low CP level); Group B = 13\% CP (low CP level); Group C $=16 \%$ 
CP (normal CP level). Groups A and B were supplemented with L-lysine, L-methionine, L-threonine, and L-tryptophan (see Table 3).

Table 8. Dynamics alterations of low-protein diets affect gene expression levels of digestive enzymes from

growing and finishing pigs.

\begin{tabular}{|c|c|c|c|c|c|}
\hline Items & Group A & Group B & Group C & $P$ value & SEM \pm \\
\hline \multicolumn{6}{|c|}{ Growing pigs (Experiment 11) } \\
\hline Trypsinogen & 1.18 & 1.31 & 1.00 & 0.35 & 0.09 \\
\hline $\mathrm{PA}^{2} \mathrm{~A}^{2}$ & 1.29 & 1.35 & 1.00 & 0.07 & 0.11 \\
\hline РCPB15 & $1.36^{\mathrm{a}}$ & $1.31^{\mathrm{a}}$ & $1.00^{\mathrm{b}}$ & 0.005 & 0.11 \\
\hline Duodenal enterokinase & 0.91 & 0.94 & 1.00 & 0.64 & 0.03 \\
\hline Chymotrypsin B & 0.78 & 0.74 & 1.00 & 0.12 & 0.08 \\
\hline Chymotrypsin C & $0.79^{b}$ & $0.85^{\mathrm{ab}}$ & $1.00^{\mathrm{a}}$ & 0.04 & 0.06 \\
\hline Pancreatic $\alpha$-amylase 2B & 1.15 & 1.12 & 1.00 & 0.34 & 0.05 \\
\hline Pancrelipase & 0.81 & 0.77 & 1.00 & 0.06 & 0.07 \\
\hline Jejunal Maltase & 1.01 & 1.00 & 1.00 & 0.99 & 0.00 \\
\hline Jejunal Sucrase & 1.13 & 1.05 & 1.00 & 0.58 & 0.04 \\
\hline Jejunal Dipeptidase-II & $1.23^{\mathrm{a}}$ & $1.19^{\mathrm{ab}}$ & $1.00^{\mathrm{b}}$ & 0.04 & 0.07 \\
\hline \multicolumn{6}{|c|}{ Growing pigs (Experiment $2^{3}$ ) } \\
\hline Trypsinogen & $0.72^{\mathrm{a}}$ & $1.06^{\mathrm{b}}$ & $1.00^{\mathrm{b}}$ & $<0.001$ & 0.23 \\
\hline PA2A2 & $0.89^{a}$ & $1.12^{\mathrm{ab}}$ & $1.00^{\mathrm{b}}$ & 0.06 & 0.12 \\
\hline РCPB15 & 0.90 & 1.11 & $1.00^{\mathrm{b}}$ & 0.10 & 0.11 \\
\hline Duodenal enterokinase & $1.65^{\mathrm{a}}$ & $1.12^{\mathrm{b}}$ & $1.00^{\mathrm{b}}$ & 0.01 & 0.12 \\
\hline Chymotrypsin B & $1.75^{\mathrm{a}}$ & $1.25^{\mathrm{b}}$ & $1.00^{\mathrm{b}}$ & 0.005 & 0.11 \\
\hline Chymotrypsin C & $1.78^{\mathrm{a}}$ & $1.24^{\mathrm{b}}$ & $1.00^{\mathrm{b}}$ & $<0.001$ & 0.13 \\
\hline Pancreatic $\alpha$-amylase 2B & 1.15 & 1.33 & 1.00 & 0.38 & 0.06 \\
\hline Pancrelipase & 1.14 & 1.02 & 1.00 & 0.44 & 0.05 \\
\hline Jejunal Maltase & 1.05 & 0.88 & 1.00 & 0.23 & 0.11 \\
\hline Jejunal Sucrase & 1.14 & 0.91 & 1.00 & 0.14 & 0.08 \\
\hline Jejunal Dipeptidase-II & $0.88^{\mathrm{a}}$ & $1.08^{\mathrm{ab}}$ & $1.00^{\mathrm{b}}$ & 0.02 & 0.13 \\
\hline \multicolumn{6}{|c|}{ Finishing pigs (Experiment $3^{4}$ ) } \\
\hline Trypsinogen & $0.76^{\mathrm{a}}$ & $0.95^{\mathrm{b}}$ & $1.00^{\mathrm{b}}$ & 0.01 & 0.08 \\
\hline PA2A2 & 0.78 & 1.04 & 1.00 & 0.11 & 0.10 \\
\hline РCPB15 & 0.77 & 1.03 & $1.00^{\mathrm{b}}$ & 0.13 & 0.11 \\
\hline Duodenal enterokinase & 1.12 & 0.87 & 1.00 & 0.09 & 0.07 \\
\hline Chymotrypsin B & $1.29^{a}$ & $1.01^{\mathrm{ab}}$ & $1.00^{\mathrm{b}}$ & 0.04 & 0.07 \\
\hline Chymotrypsin C & $0.79^{b}$ & $0.85^{\mathrm{ab}}$ & $1.00^{\mathrm{a}}$ & 0.04 & 0.06 \\
\hline Pancreatic $\alpha$-amylase 2B & 0.82 & 1.00 & 1.00 & 0.24 & 0.07 \\
\hline Pancrelipase & 1.02 & 0.86 & 1.00 & 0.34 & 0.14 \\
\hline Jejunal Maltase & 0.89 & 0.94 & 1.00 & 0.77 & 0.29 \\
\hline Jejunal Sucrase & 0.99 & 0.92 & 1.00 & 0.81 & 0.54 \\
\hline Jejunal Dipeptidase-II & $0.83^{\mathrm{b}}$ & $1.00^{\mathrm{a}}$ & $1.00^{\mathrm{a}}$ & 0.05 & 0.07 \\
\hline
\end{tabular}

Data are means with the pooled means \pm standard error of the mean (SEM), $n=6 /$ treatment group. Within a row, values with different superscript letters differ $(\mathrm{P}<0.05)$. The average initial weight for the four periods was showed in Table 4. ${ }^{2} \mathrm{PA} 2 \mathrm{~A}=$ pancreatic $\alpha$-amylase $2 \mathrm{~A}$; $5 \mathrm{PCPB} 1=$ pancreatic carboxypeptidase $\mathrm{B} 1 ; \mathrm{CP}=$ crude protein; $\mathrm{IDAA}=$ ileal digesta of amino acids; ${ }^{1}$ Experiment 1: Group $\mathrm{A}=14 \% \mathrm{CP}$ (very low $\mathrm{CP}$ level); Group B $=17 \% \mathrm{CP}$ (low CP level); Group C $=20 \% \mathrm{CP}$ (normal CP level). Groups A and B were supplemented with L-lysine, L-methionine, L-threonine, and L-tryptophan (see Table 1). ${ }^{3}$ Experiment 2: Group A $=12 \%$ CP (very low CP level); Group B $=15 \%$ CP (low CP level); Group C $=18 \%$ CP (normal CP level). Groups A and B were supplemented with L-lysine, L-methionine, L-threonine, and L-tryptophan (see Table 2). ${ }^{4}$ Experiment 3: Group A $=10 \% \mathrm{CP}$ (very low $\mathrm{CP}$ level); Group B $=13 \%$ CP (low CP level); Group C $=16 \% \mathrm{CP}$ (normal CP level). Groups 
A and B were supplemented with L-lysine, L-methionine, L-threonine, and L-tryptophan (see Table 3).

\section{Discussion}

The results of this study support the concept that a substantial reduction of three percentage units of dietary $\mathrm{CP}$, while maintaining adequate supplies of essential AA allowed for a significant decrease in total $\mathrm{N}$ excretion without negative effect on ADG, ADFI or F: G. The supplementary essential AA were L-lysine, L-methionine, L-threonine and L-tryptophan. However, maximal growth performance and ADFI in different stages of pigs depended on adequate provision of AA that can be synthesized by pigs [24,25]. In the present study, we sought to evaluate the dynamic effects of a 3- or 6-percentage unit reduction in dietary protein, while supplementing the diets with essential AA on weight gain and digestibility in pigs. The results indicated that a reduction in dietary $\mathrm{CP}$ by 3-percentage units with a concomitant addition of essential AA would support similar growth performance and feed efficiency from Experiment 1 to Experiment 3 . However, a substantial reduction on in dietary $\mathrm{CP}$ by 6-percentage units had a negative impact on growth performance in Experiment 1 and Experiment 2, but there was a slight enhancement in growth performance in Experiment 3. Similar results were obtained by some other researchers $[9,11,26]$, and the results were not consist with consistent with previous results that showed finishing pigs fed the $16 \% \mathrm{CP}$ diet had higher $(\mathrm{P}<0.01)$ final BW compared to pigs those fed the $10 \% \mathrm{CP}$ diet [2]. In addition to this result, the reduction in total $\mathrm{N}$ excretion was mainly caused by a reduction in urinary excretion. In our experiment, reducing the dietary $\mathrm{CP}$ level from 20 to $14 \%$ decreased urinary $\mathrm{N}$ excretion by $52.8 \%$ (P $<0.001$ ) in Experiment 1. Reducing the dietary $\mathrm{CP}$ level from 18 to $12 \%$ decreased urinary $\mathrm{N}$ excretion by $55.3 \% \quad(\mathrm{P}<0.001)$ and fecal $\mathrm{N}$ excretion by $34 \%(\mathrm{P}<0.05)$ in Experiment 2 . Reducing the dietary $\mathrm{CP}$ level from 10 to $16 \%$ decreased urinary $\mathrm{N}$ excretion by $56.4 \% \quad(\mathrm{P}<0.001)$ and fecal $\mathrm{N}$ excretion by $47.1 \%(\mathrm{P}<0.001)$ in Experiment 3 (Table 6). This finding was not consistent with previous results showing there was a decrease in urinary $\mathrm{N}$ but not in fecal $\mathrm{N}$ excretion when lowering dietary $\mathrm{CP}$ from $16.9-15.6$ to $14.6-13.5 \%$ for growing and finishing pigs [27]. The outcomes were consistent with previous results showing that a decrease in urinary $\mathrm{N}$ by $65 \%$ and fecal $\mathrm{N}$ excretion by $31 \%$ occurred when dietary $\mathrm{CP}$ was lowered from 20 to $12 \%$ for fattening pigs [28]. A possible explanation for discrepancies between this study and our present study could be that the effects of growth performance and $\mathrm{N}$ balance depend on the pig species, different diet formulations and different stages.

The results for the ileal digestibility of $\mathrm{CP}$ and certain $\mathrm{AA}$ in diets used for the 3 stages in the present study differed significantly. A reduction of 6-percentage units of dietary $\mathrm{CP}$ produced the highest ileal digestibility for $\mathrm{CP}$ and AA (Table 7). This finding is consistent with previous results $[2,29]$. The $\mathrm{CP}$ and AA ileal digestibility mainly depend on relative increases in the rates of protein digestion and absorption of the resulting products by the small intestine. Several previous studies also support the concept that synthetic crystalline AA (including essential AA) are fully available to the small intestine, whereas not all AA in dietary proteins are released by digestive proteases in the gut lumen [2,30-32]. In the present study, a reduction of 3-percentage units and supplementation with adequate amounts of AA just met the nutritional requirements for pigs. However, when dietary $\mathrm{CP}$ is reduced by 6-percentage units and supplemented with adequate amounts of AA, growth performance and feed efficiency are affected in growing pigs and finishing pigs, even though the AID of AA improved.

Some studies on pigs have shown that the activity of the digestive enzymes and their response to different dietary formulations evaluate how effectively a given diet can promote animal growth $[33,34]$. The digestion of dietary CP and carbohydrates in pigs depends on different kinds of digestive enzymes in the gastrointestinal tract, such as trypsinogen, pancreatic $\alpha$-amylase $2 \mathrm{~A}$, pancreatic carboxypeptidase B1, duodenal enterokinase, chymotrypsin B, chymotrypsin C, pancreatic $\alpha$-amylase 2B, pancrelipase, jejunal maltase, jejunal sucrose, and jejunal dipeptidase-II. In the present study, pigs fed the very low $(14 \%, 12 \%$, and $10 \% \mathrm{CP})$ diets showed higher mRNA levels 
for chymotrypsin $\mathrm{C}(\mathrm{P}<0.01$ in Experiment 1 and 2; $\mathrm{P}<0.05$ in Experiment 3) compared to pigs fed the normal $(20 \%, 18 \%$, and $16 \% \mathrm{CP})$ diets among the three experiments. Thus, our results indicate that dynamic intestinal expression of the genes for protein digestion is reduced in response to two levels of low-protein diets. We also observed an increase in intestinal mRNA levels for chymotrypsin $\mathrm{C}$ in Experiment 1 and Experiment 3 after animals were fed low-protein diets. However, this value decreased in Experiment 2. This finding is not consistent with previous results showing that an increase in intestinal mRNA levels for chymotrypsins B and C as well as duodenal enterokinase in growing and finishing pigs that were fed low-protein diets [2]. A possible explanation for the discrepancies between the previous study and our present study could be that the mRNA levels for digestive enzymes depend on the pig species and that different stages are subjected to complex regulation at both transcriptional and translational levels by a series of factors, including the content and balance of dietary AA. Future studies are needed to determine the protein abundance of digestive enzymes in pigs fed low-protein and adequate $\mathrm{CP}$ diets.

\section{Conclusions}

In conclusion, two levels of low-protein diets supplemented with essential AA can dynamically affect $\mathrm{N}$ balance, digestive enzymes and ileal AA digestibility from growing pigs to finishing pigs, and there were gains in weight and feed efficiency in 30-45 kg (Experiment 2) and 45-80 kg (Experiment 3) pigs when dietary $\mathrm{CP}$ was reduced by 3-percentage units. Low-protein diets supplemented with nutritionally essential AA alone cannot maintain weight gains or feed efficiency in growing pigs alone (Experiment 1). These novel findings have potential implications for the development of methods to ameliorate dietary protein shortage and N-triggered environmental pollution from swine production.

Supplementary Materials: The following are available online at www.mdpi.com/link, Figure S1: title, Table S1: title, Video S1: title.

Acknowledgments: This research was supported by the Fujian Provincial Science and Technology Department and Chinese Academy of Sciences Supporting Project of STS Program (2019T3033), the Technical Innovation Guidance Project of Guangxi Zhuang Autonomous Region Science and Technology Department (2018AC01007), and by the Natural Science Foundation of Hunan Province (2018JJ2464).

Author Contributions: P.L conceived and designed the experiments. L.W. performed the experiments and analyzed the data. P.L. wrote the first draft of the manuscript. W.Z. and Q.H. contributed reagents/materials/analytical tools.

Conflicts of Interest: The authors declare no conflict of interest. The founding sponsors had no role in the design of the study; in the collection, analyses, or interpretation of data; in the writing of the manuscript, and in the decision to publish the results. 


\section{References}

1. $\mathrm{Wu}, \mathrm{G}$. Amino acids: Metabolism, functions, and nutrition. Amino acids 2009, 37, 1-17.

2. He, L.; Wu, L.; Xu, Z.; Li, T.; Yao, K.; Cui, Z.; Yin, Y.; Wu, G. Low-protein diets affect ileal amino acid digestibility and gene expression of digestive enzymes in growing and finishing pigs. Amino acids 2016, 48, 21-30.

3. Acciaioli, A.; Sirtori, F.; Pianaccioli, L.; Campodoni, G.; Pugliese, C.; Bozzi, R.; Franci, O. Comparison of total tract digestibility and nitrogen balance between cinta senese and large white pigs fed on different levels of dietary crude protein. Anim Feed Sci Tech 2011, 169, 134-139.

4. Deng, D.; Huang, R.; Li, T.; Wu, G.; Xie, M.; Tang, Z.; Kang, P.; Zhang, Y.; Fan, M.; Kong, X. Nitrogen balance in barrows fed low-protein diets supplemented with essential amino acids. Livestock Science 2007, 109, 220-223.

5. Hou, Z.P.; Yin, Y.L.; Huang, R.L.; Li, T.J.; Hou, R.; Liu, Y.; Wu, X.; Liu, Z.; Wang, W.; Xiong, H. Rice protein concentrate partially replaces dried whey in the diet for early-weaned piglets and improves their growth performance. Journal of the science of food and agriculture 2008, 88, 1187-1193.

6. Kerr, B.; Southern, L.; Bidner, T.; Friesen, K.; Easter, R. Influence of dietary protein level, amino acid supplementation, and dietary energy levels on growing-finishing pig performance and carcass composition. Journal of animal science 2003, 81, 3075-3087.

7. Opapeju, F.; Krause, D.; Payne, R.; Rademacher, M.; Nyachoti, C. Effect of dietary protein level on growth performance, indicators of enteric health, and gastrointestinal microbial ecology of weaned pigs induced with postweaning colibacillosis. Journal of animal science 2009, 87, 2635-2643.

8. Cromwell, G. Synthetic amino acid may improve performance, reduce nitrogen excretion. Feedstuffs (USA) 1996.

9. Tuitoek, K.; Young, L.; De Lange, C.; Kerr, B. The effect of reducing excess dietary amino acids on growing-finishing pig performance: An elevation of the ideal protein concept. Journal of animal science 1997, 75, 1575-1583.

10. Hahn, J.D.; Biehl, R.R.; Baker, D.H. Ideal digestible lysine level for early-and late-finishing swine. Journal of animal science 1995, 73, 773-784.

11. Kerr, B.; Easter, R. Effect of feeding reduced protein, amino acid-supplemented diets on nitrogen and energy balance in grower pigs. Journal of animal science 1995, 73, 3000-3008.

12. Figueroa, J.; Lewis, A.; Miller, P.; Fischer, R.; Gómez, R.; Diedrichsen, R. Nitrogen metabolism and growth performance of gilts fed standard corn-soybean meal diets or low-crude protein, amino acid-supplemented diets. Journal of animal science 2002, 80, 2911-2919.

13. Hansen, J.A.; Knabe, D.; Burgoon, K. Amino acid supplementation of low-protein sorghum-soybean meal diets for 20-to 50-kilogram swine. Journal of animal science 1993, 71, 442-451.

14. Gómez, R.; Lewis, A.; Miller, P.; Chen, H. Growth performance, diet apparent digestibility, and plasma metabolite concentrations of barrows fed corn-soybean meal diets or low-protein, amino acid-supplemented diets at different feeding level. Journal of animal science 2002, 80, 644-653.

15. Jagger, S.; Wiseman, J.; Cole, D.; Craigon, J. Evaluation of inert markers for the determination of ileal and faecal apparent digestibility values in the pig. British Journal of Nutrition 1992, 68, 729-739.

16. NRC. Nutrient requirements of swine: Eleventh revised edition. The National Academies Press: Washington, DC, USA, 2012.

17. Wang, W.; Dai, Z.; Wu, Z.; Lin, G.; Jia, S.; Hu, S.; Dahanayaka, S.; Wu, G. Glycine is a nutritionally essential amino acid for maximal growth of milk-fed young pigs. Amino acids 2014, 46, 2037-2045.

18. Heo, K.; Odle, J.; Han, I.K.; Cho, W.; Seo, S.; van Heugten, E.; Pilkington, D.H. Dietary l-carnitine improves nitrogen utilization in growing pigs fed low energy, fat-containing diets. The Journal of nutrition 2000, 130, 1809-1814.

19. AOAC. Official methods of analysis. Assoc. Off. Anal. Chem., Arlington, VA 1990, 1, 684.

20. Wang, W.; Dai, Z.; Wu, Z.; Lin, G.; Jia, S.; Hu, S.; Dahanayaka, S.; Wu, G. Glycine is a nutritionally essential amino acid for maximal growth of milk-fed young pigs. Amino acids 2014, 46, 2037-2045.

21. Dai, Z.; Wu, Z.; Jia, S.; Wu, G. Analysis of amino acid composition in proteins of animal tissues and foods as pre-column o-phthaldialdehyde derivatives by hplc with fluorescence detection. Journal of Chromatography B 2014, 964, 116-127. 
22. Wu, L.; Liao, P.; He, L.; Ren, W.; Yin, J.; Duan, J.; Li, T. Growth performance, serum biochemical profile, jejunal morphology, and the expression of nutrients transporter genes in deoxynivalenol (don)challenged growing pigs. BMC veterinary research 2015, 11, 144.

23. Wu, L.; Liao, P.; He, L.; Feng, Z.; Ren, W.; Yin, J.; Duan, J.; Li, T.; Yin, Y. Dietary l-arginine supplementation protects weanling pigs from deoxynivalenol-induced toxicity. Toxins 2015, 7, 1341-1354. 24. Wu, G.; Wu, Z.; Dai, Z.; Yang, Y.; Wang, W.; Liu, C.; Wang, B.; Wang, J.; Yin, Y. Dietary requirements of "nutritionally non-essential amino acids" by animals and humans. Amino acids 2013, 44, 1107-1113.

25. Hou, Y.; Yin, Y.; Wu, G. Dietary essentiality of "nutritionally non-essential amino acids" for animals and humans. Experimental biology and medicine 2015, 240, 997-1007.

26. Gallo, L.; Dalla Montà, G.; Carraro, L.; Cecchinato, A.; Carnier, P.; Schiavon, S. Growth performance of heavy pigs fed restrictively diets with decreasing crude protein and indispensable amino acids content. Livestock Science 2014, 161, 130-138.

27. Gatel, F.; Grosjean, F. Effect of protein content of the diet on nitrogen excretion by pigs. Livest Prod Sci 1992, 31, 109-120.

28. Portejoie, S.; Dourmad, J.; Martinez, J.; Lebreton, Y. Effect of lowering dietary crude protein on nitrogen excretion, manure composition and ammonia emission from fattening pigs. Livest Prod Sci 2004, 91, 45-55.

29. Kulthe, A.A.; Pawar, V.D.; Kotecha, P.M.; Chavan, U.D.; Bansode, V.V. Development of high protein and low calorie cookies. Journal of food science and technology 2014, 51, 153-157.

30. $\mathrm{Wu}, \mathrm{G}$. Dietary requirements of synthesizable amino acids by animals: A paradigm shift in protein nutrition. Journal of animal science and biotechnology 2014, 5, 34.

31. Awad, E.A.; Fadlullah, M.; Zulkifli, I.; Farjam, A.S.; Chwen, L.T. Amino acids fortification of low-protein diet for broilers under tropical climate: Ideal essential amino acids profile. Italian Journal of Animal Science 2014, 13, 3166.

32. Hansen, M.J.; Nørgaard, J.V.; Adamsen, A.P.S.; Poulsen, H.D. Effect of reduced crude protein on ammonia, methane, and chemical odorants emitted from pig houses. Livestock Science 2014, 169, 118-124.

33. Guzmán-Pino, S.A.; Solà-Oriol, D.; Figueroa, J.; Pérez, J.F. Influence of the protein status of piglets on their ability to select and prefer protein sources. Physiology \& behavior 2014, 129, 43-49.

34. Pérez-Jiménez, A.; Cardenete, G.; Morales, A.E.; García-Alcázar, A.; Abellán, E.; Hidalgo, M.C. Digestive enzymatic profile of dentex dentex and response to different dietary formulations. Comparative Biochemistry and Physiology Part A: Molecular \& Integrative Physiology 2009, 154, 157-164. 